\title{
HYPOXIA INDUCIBLE FACTOR-1-ALPHA EXPRESSION ON PREECLAMPSIA MICE MODEL WITH L-ARGININE ADMINISTRATION
}

\author{
Nutria Widya Purna Anggraini ${ }^{1}$, Sri Sulistyowati ${ }^{1}$, Muhammad Adrianes Bachnas ${ }^{1}$, Wisnu Prabowo ${ }^{1}$, Uki \\ Retno Budihastuti ${ }^{1}$ \\ 1 Department of Obstetrics and Gynecology, Faculty of Medicine, Universitas Sebelas Maret, Surakarta, \\ Indonesia/Dr. Moewardi Hospital, Surakarta, Indonesia
}

\begin{abstract}
Preeclampsia is hypertension in pregnancy that affects $2 \%$ to $8 \%$ of pregnancies worldwide and causes significant maternal and perinatal morbidity and mortality. In the pathogenesis of preeclampsia, placental hypoxia plays an important role, associated with excessive trophoblast apoptosis resulting in decreased trophoblast and spiral arteries invasion. This placental hypoxic condition will induce increased expression of Hypoxia Inducible Factor -1-Alpha (HIF-1-A). L-Arginine is a potent vasodilator presumably to improve preeclampsia placental hypoxic conditions and reduce HIF-1-A expression. This study was an experimental study with a parallel-group post-test only design. Thirty-six preeclamptic mice models were divided into 2 groups. The control group (K1) 18 preeclamptic mice model without treatment and the treatment group (K2) 18 preeclamptic mice given L-Arginine. The independent variable was the administration of L-Arginine and the dependent variable is the placental HIF-1-A expression. Statistical analysis used unpaired t-test on normal data distribution, and Mann Whitney test on abnormal data distribution. The mean of placental HIF-1-A expression K1 was $2.47 \pm 1.65$ with a minimum value of 0.4 and a maximum value of 6.6. At K2 $0.93 \pm 0.55$ with a minimum value of 0.0 and a maximum value of 2.0. Statistical tests showed that the placental HIF-1-A expression in the treatment group was significantly lower than that in the control group $(p<0.001)$. In conclusion, the expression of HIF-1-A in preeclamptic mice model placenta decreased with L-Arginine administration.
\end{abstract}

Keywords: HIF-1-A; preeclampsia mouse model; L-Arginine; maternal health

\section{ABSTRAK}

Preeklamsia merupakan hipertensi dalam kehamilan yang mempengaruhi $2 \%$ sampai $8 \%$ kehamilan di seluruh dunia serta menyebabkan morbiditas dan mortalitas maternal dan perinatal yang signifikan. Pada patogenesis preeklampsia hipoksia plasenta memegang peranan penting, berhubungan dengan apoptosis trofoblas yang berlebihan sehingga terjadi penurunan invasi trofoblas dan arteri spiralis. Kondisi hipoksia plasenta ini akan menginduksi ekspresi Hypoxia Inducible Factor -1Alpha (HIF-1-A) yang meningkat. L-Arginin sebagai vasodilator kuat diduga dapat memperbaiki kondisi hipoksia plasenta preeclampsia, dan menurunkan ekspresi HIF-1-A. Penelitian ini merupakan penelitian eksperimental dengan parallel group post-test only design. Tigapuluh enam mencit model preeclampsia dibagi 2 kelompok. Kelompok kontrol (K1)18 mencit model preeklampsia tanpa perlakuan dan kelompok perlakuan (K2) 18 mencit model preeklampsia diberikan L-Arginin. Variabel bebas adalah pemberian L-Arginin dan variabel tergantung ekspresi HIF-1-A plasenta. Analisa statistik mengunakan uji t tidak berpasangan pada sebaran data normal, dan uji Mann Whitney pada sebaran data tidak normal. Didapatkan rerata ekspresi

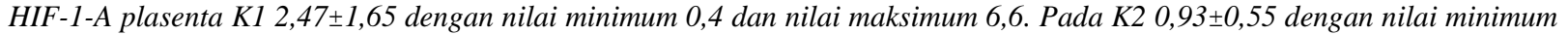
0,0 dan nilai maksimum 2,0. Uji statistik menunjukkan ekspresi HIF-1-A plasenta pada kelompok perlakuan lebih rendah secara bermakna dibanding pada kelompok kontrol ( $p<0,001)$. Sebagai simpulan ekspresi HIF-1-A pada plasenta mencit model preeklampsia menurun dengan pemberian L-Arginin.

Kata kunci: HIF-1-A; mencit model preeklampsia; L-Arginin; maternal health

Correspondence: Nutria Widya Purna Anggraini, Department of Obstetrics and Gynecology, Faculty of Medicine, Universitas Sebelas Maret, Surakarta, Indonesia/Dr. Moewardi Hospital, Surakarta, Indonesia 57126. Email: nutria_dr@yahoo.co.id

pISSN:2355-8393 • eISSN: 2599-056x • doi: 10.20473/fmi.v57i3.22733

- Fol Med Indones. 2021;57:226-230 • Submitted 22 Oct $2020 \bullet$ Received 30 Mar $2021 \bullet$ Accepted 17 Apr 2021

- Open access under CC-BY-NC-SA license • Available at https://e-journal.unair.ac.id/FMI/ 


\section{INTRODUCTION}

Preeclampsia is a pregnancy complication with a global incidence of 4-5\% (Zhang et al 2020). According to World Health Organization, the incidence of preeclampsia in developing countries is seven times higher in developing countries (Kooffreh 2014). In Indonesia, preeclampsia is the three main causes of maternal death. Apart from bleeding and infection, preeclampsia is characterized by hypertension with or without proteinuria after 20 weeks of pregnancy (Rezky 2020). The exact etiology of preeclampsia is unknown, so that it is called the "disease of theory" (Uzan 2011).

During the last decades, there have been many substantial advances in the pathophysiology of preeclampsia. The placenta plays an important role in the development of preeclampsia (Kedia 2016). It has been demonstrated that placental hypoxia is considered a major factor contributing to the pathogenesis of preeclampsia, and is associated with excessive trophoblast apoptosis, resulting in decreased trophoblast invasion and insufficient remodeling of the spiral arteries (Zhang et al 2020). Impaired implantation of extravillous trophoblasts from the spiral arteries resulting in decreased placental perfusion and intermittent arterial blood flow became ischemia and creates an environment of oxidative stress.

Oxidative damage in the placenta causes inflammation, apoptosis, and release of cellular debris into the maternal circulation, along with several anti-angiogenic factors, such as soluble FMS-like tyrosine kinase-1 (sFlt1) and soluble endoglin (sEng), cytokines, and oxidants. Besides, in preeclampsia, there is also a decrease in the angiogenic factor of Vascular Endothelial Growth Factor (VEGF) which functions to trigger blood vessel remodeling in hypoxic cells. in the hypoxic preeclamptic placental condition, VEGF induces overexpression of Hypoxia-Inducible Factor-1 (HIF-1) in the placental tissue. HIF-1 is an important regulator of oxygen homeostasis for placental development. HIF-1 consists of the HIF-1-A and HIF-1B subunits. HIF-1-A that is active will inhibit the differentiation of trophoblast cells, and in preeclampsia, there is an increase in placental HIF-1-A (Albers 2019).

Based on the pathogenesis of placental hypoxia in preeclampsia, it is proven that increasing HIF-1-A as a marker of hypoxia can be a new thought in the prevention and treatment of preeclampsia. The study of Zhang et al (2020) examined the expression level of HIF-1-A at placental tissue in a hypoxic state. The results of HIF-1-A expression are relatively high in the placental tissue of patients with preeclampsia and hypoxic conditions. Increased expression of HIF-1-A increases trophoblast apoptosis by regulating FOXO3a in the pathogenesis of preeclampsia (Zhang et al 2020). A Study by Kosovic et al (2020) also reported significantly higher immunohistochemically expression of HIF-1-A in all segments of the placenta, villous trophoblast (VTB), decidual cells (DC), and extravillous trophoblast (EVTB) in the placenta preeclampsia compared to the placenta from normal pregnancies.

The treatment with the strong vasodilator L-Arginine as a precursor of $\mathrm{NO}$ is expected to reduce maternal blood pressure, improve endothelial function and reduce placental hypoxia in preeclampsia (Facchinetti 2017). Kurokawa et al (2019) used L-Arginine the NO producer to enhance the NO production, thereby increasing the intracellular porphyrin accumulation by upregulation of HCP-1 expression via HIF-1-A stabilization. NO regulates the blood flow to obtain $\mathrm{O} 2$ and decreased HIF-1-A. L-Arginine is decreased in preeclampsia compared with normal pregnancy. This occurs due to the higher absorption of L-Arginine via the human cationic amino acid transporter (hCAT) on the fetal and maternal side of the preeclamptic placenta. By administering L-Arginine, it is expected that it can improve placental hypoxia and reduce HIF-1-A (Casanello 2007). In this case, a research with human samples is not possible, so that we used experimental animals (Mus musculus) model of preeclampsia as samples as demonstrated in the study of Comiskey et al (2013).

\section{MATERIALS AND METHODS}

This study was an experimental study with a parallelgroup post-test only design. This study was conducted in the in vitro laboratory and the anatomical pathology laboratory of the Faculty of Veterinary Medicine, Universitas Airlangga, Surabaya. The research sample was mice (Mus musculus) which was taken through simple random sampling. The sampel had met the inclusion criteria, namely female mice aged 3 months, healthy, bodyweight 20-25 grams. Exclusion criteria were anatomical abnormalities that looked macroscopic, mice looked sick, inactive, and had diarrhea. The sample was divided into 2 groups, the control group (K1) $(\mathrm{n}=18)$ and the treatment group (K2) $(\mathrm{n}=18)$. Both groups were treated as preeclamptic mice by giving an intravenous anti-Qa-2 injection to eliminate the expression of Qa-2 which was analogous to the loss of HLA-G expression in humans. Administration of anti Qa-2 injection for 4 consecutive days (10 $\mathrm{ng} /$ day) 1-4 of pregnancy.

In the treatment group (K2), 7-15 days of pregnancy were given L-Arginine $500 \mathrm{mg} / \mathrm{kgBW} /$ oral, because it 
was analogous to the 7 th day of pregnancy in mice. Besides, the implantation had been completed and the placentation stage begins with trophoblasts invading the uterus. The control group was not given therapy. On the 16 th day of pregnancy, the mice were operated on and placenta samples were taken. The reason for taking on the 16th day was assumed to be the same as the second trimester of pregnancy in humans, where in the second trimester, the manifestations of preeclampsia appeared in humans. Subsequently, paraffin block preparations were made on placental samples and immunohistochemically examinations were carried out to see the expression of HIF-1-A.

The independent variable was the administration of LArginine in preeclamptic pregnant mice. The dependent variable was expression of placental Hypoxia Inducible Factor 1 alpha (HIF-1-A). The expression of HIF-1-A was shown by the chromogen golden brown color on the trophoblast. The expression of HIF 1-A on placental trophoblast cells was assessed semi-quantitatively according to the Ramelle method. Data analysis was using SPSS (Software Package for Social Science). The statistical test was performed, namely the unpaired t-test on normal data distribution, and the Mann Whitney test on abnormal data distribution. The statistical calculation used a significance level of $0.05 \quad(95 \%$ confident interval), so that if the statistical test was obtained, $\mathrm{p}$ $<0.05$ could be interpreted as significant. This study had been approved by the Ethical Committee at the Faculty of Veterinary Medicine, Faculty of Medicine, Universitas Airlangga with a decree No: 648-KE 19 October 2017.

\section{RESULTS}

The expression of placental HIF-1-A in each study group was shown in the following table.

Table 1. Placental HIF-1-A expression

\begin{tabular}{lllllll}
\hline $\begin{array}{l}\text { HIF-1-A placental } \\
\text { expression (per 10 }\end{array}$ & $\mathrm{N}$ & Mean & SD & Min & Max & $\mathrm{p}$ \\
field of view & & & & & & \\
\hline $\mathrm{K} 1$ & 18 & 2.47 & 1.65 & 0.4 & 6.6 & $<0.001^{*}$ \\
$\mathrm{~K} 2$ & 18 & 0.93 & 0.55 & 0.0 & 2.0 & \\
\hline * CI 95 \% p $<0,05$ & & & & & \\
\end{tabular}

Table 1 showed that the mean placental HIF-1-A expression in the K2 group (treatment) wAS $0.93 \pm$ 0.55. It was significantly lower than the K1 (control) group mean placental HIF-1-A expression, that was 2.47. $\pm 1.65(\mathrm{p}<0.001)$.

Besides, comparison expression of placental HIF-1-A in each study group was also shown in Figure 1.

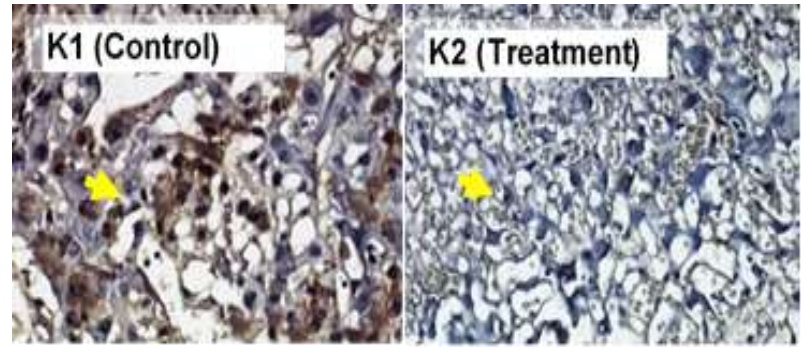

Figure 1. Expression of HIF-1-A chromogen brown on capillary walls and placental trophoblast cells (arrow) in the control and groups treatment. (Immunohistochemically staining; 400X magnification; Nikon H600L microscope; 300 megapixel DS Fi2 camera)

The previous figure indicated that the chromogen brown color of HIF-1-A expression in the K1 (control) group was stronger than the $\mathrm{K} 2$ (treatment) group, while in the treatment group, the HIF-1-A expression was weak until there had no HIF-1 expression found.

\section{DISCUSSION}

From the study's results with observation of HIF-1-A expression in preeclampsia mice model obtained significant results, that was the reduced HIF-1-A expression in the treatment group with L-Arginine administration $(p<0.001)$. The result of this study was in accordance with the hypothesis. Relevant to this case, Albers et al (2019) pointed out that excessive HIF-1-A expression in trophoblasts caused the failure of spiral artery implantation. These placental changes result in hypertension and maternal renal glomeruloendotheliosis with accompanying proteinuria, a classic feature of preeclampsia. This suggests that the overexpression of HIF-1-A in the placental trophoblast causes the pathophysiology of preeclampsia. Increased HIF-1-A in human placenta is associated with preeclampsia (PE).

Likewise, in Gathiram's study, it was said that HypoxiaInducible Factor 1 Alpha (HIF-1-A) is the main regulatory component in trophoblast differentiation. Placentogenesis is strongly influenced by oxygen regulation. Abnormalities in the early development of the placenta, ranging from inadequate trophoblast invasion to spiral arteries, leading to decreased uteroplacental perfusion and resulting in placental hypoxia. Placental hypoxia increases oxidative stress and activation of the inducible-1 $\alpha$ (HIF-1-A) indifferent pathway (Gathiram 2016).

This study was also relevant to a study stating that there is a decrease in the concentration of L-Arginine. LArginine in preeclampsia, where it is a potent 
vasodilator to improve placental hypoxia in preeclampsia, especially during placentation and angiogenesis. L-Arginine deficiency as a substrate for NO synthesis, is associated with the development of preeclampsia in high-risk populations (Vadillo-Ortega 2011). Besides, in another study, serum L-Arginine levels were found to be low in complicated preeclampsia (28.33 $\mathrm{ng} / \mathrm{mL}$ ), followed by severe preeclampsia (34.66 $\mathrm{ng} / \mathrm{mL}$ ), and the highest was in normal pregnant women $(60.91 \mathrm{ng}) . / \mathrm{mL})$. Therefore, giving L-Arginine is considered to improve the condition of preeclampsia (Heldayanti 2020).

Furthermore, L-Arginine prolongs the developmental latency of preeclampsia in a high-risk female population (Holwerda et al 2013, Chen et al 2016). Another study also resulted L-Arginine supplementation through drinking water, gavage, or injection reducing maternal hypertension in several models of preeclamptic mice, and there was an increase in vascular function including an increase in placental perfusion in mice infused with L-NAME (Gatford et al 2020). A good perfusion will lead to an adequate supply of blood flow intervilli space, so that the smooth muscle cells tunica media does not proliferate, tunica intima is not thickened. Thus, the diameter of the corial villi artery does not narrow.

L-Arginine supplementation is useful in the management of preeclampsia cases (Al-Bayati 2014). Besides, a good perfusion of blood flow will prevent the occurrence of continuous hypoxia, thus improving the condition of placental hypoxia associated with decreased HIF-1-A expression and improvement of preeclamptic symptoms. Therefore, giving L-Arginine was proven effective to repair endothelial damage by reducing intimal hyperplasia, atherosis and spiral artery thickness in preeclamptic mice (Soetrisno 2017).

Another case was that administering L-Arginine to mice had an indication that L-Arginine caused villous vascular dilation in the placenta by finding $\mathrm{NO}$ in the umbilical endothelium, chorionic discs and villi blood vessels which contributed to the maintenance of basal vascular tone and attenuates the action of vasoconstrictors, such as endothelin (ET-1) and thromboxane (Al-Bayati 2014). In this study, it was proven that the administration of L-Arginine 500 $\mathrm{mg} / \mathrm{kg} /$ day/oral decreased the expression of placental HIF-1-A as a marker of placental hypoxia and improved the hypoxic condition of the placenta in preeclamptic mice. It was expected that giving L-Arginine could improve hypoxic conditions in preeclampsia and become a therapeutic option for preeclampsia and its complications prevention.

\section{CONCLUSION}

The expression of HIF-1-A in the placenta of preeclampsia mice models decreased significantly with L-Arginine administration.

\section{REFERENCES}

Al-Bayati M, Ahmad M, Khamas W (2014). The potential effect of L-arginine on mice placenta. Advances in Pharmacoeidemiology \& Drug Safety 3, $1-9$.

Albers RE, Kaufman MR, Natale BV, et al (2019). Trophoblast-specific expression of hif- $1 \alpha$ results in preeclampsia-like symptoms and fetal growth restriction. Sci Rep 9, 1-13.

Casanell P, Escudero C, Sobrevia L (2007). Equilibrative nucleoside (ents) and cationic amino acid (cats) transporters: Implications in foetal endothelial dysfunction in human pregnancy diseases. Current Vascular Pharmacology 5, 69-84.

Chen J, Gong X, Chen P, et al (2016). Effect of Larginine and sildenafil citrate on intrauterine growth restriction fetuses: a meta-analysis. BMC Pregnancy and Childbirth 16, 1-20.

Comiskey M, Warner CM, Schust DJ (2013). MHC molecules of the preimplantation embryo and trophoblast. Madame Curie Bioscience Database. Available from http://www.ncbi.nlm.nih. Accessed Dec 9, 2020.

Facchinett F, Farulla A (2017). Dietary supplements and drugs for preeclampsia prophylaxis. Journal of Women's Cardiovascular Health 7, 59.

Garford KL, Andraweera PH, Roberts CT, et al (2020). Animal models of preeclampsia: Causes, consequences, and interventions. Hypertension 75, 1363-1381.

Gathiram P, Moodley J (2016). Preeclampsia: Its pathogenesis and pathophysiology. Cardiovascular Journal of Africa 27, 71-8.

Holwerda KM, Faas MM, van Goor H, et al (2013). A solution for the therapeutic dilemma in preeclampsia?. Hypertension 62, 653-659.

Kedia K, Smith SF, Wright AH, et al (2016). Global 'omics' evaluation of human placental responses to preeclamptic conditions. Am J Obstet Gynecol 215, 125.

Kooffreh ME, Ekott M, Ekpoudom DO (2014). The prevalence of preeclampsia among pregnant women in the University of Calabar Teaching Hospital, Calabar. Saudi J Health Sci 3, 133-136.

Kosovic I, Prusac IK, Mestrovic Z, et al (2020). HIF- $1 \alpha$ immunohistochemical expression in decidual cells, villous and extravillous trophoblast in placentas from 
pregnancies complicated with preeclampsia. Pregnancy Hypertension 21, 176-178.

Kurokawa H, Ito H, Terasaki M, et al. (2019). Nitric oxide regulates the expression of heme carrier protein1 via hypoxia inducible factor- $1 \alpha$ stabilization. PLoS One 14, 1-19.

Rezky DM, Navianti D, Nurhayati N (2020). Gambaran proteinuria pada ibu hamil trimester III di rumah sakit kota palembang tahun 2019. Journal of Indonesian Medical Laboratory and Science 1, 32-47.

Sirenden H, Sunarno I, Usman AN, et al (2020). Deficiency of serum L-Arginin levels in severe preeclampsia; a consideration for supplementation. 30, 566-9.

Soetrisno SS, Wibowo A (2017). L-Arginin improves uterine spiral arterial wall thickness in mouse models of preeclampsia. Universa Medicina 36, 131-138.
Uzan J, Carbonnel M. (2011). Preeclampsia: Pathophysiology, diagnosis and management. Vasc Health Risk Manag 7, 467-474.

Vadillo-Ortega Felipe, Perichart-Perera O, Espino S, et al (2011). Effect of supplementation during pregnancy with L- arginin and antioxidant vitamins in medical food on preeclampsia in high-risk population: Randomized controlled trial. BMJ 342, 1-8.

Zhang Z, Huang C, Wang P, et al (2020). HIF-1 $\alpha$ affects trophoblastic apoptosis involved in the onset of preeclampsia by regulating FOXO3a under hypoxic conditions. Mol Med Rep 21, 2484-2492. 